\title{
Does parenthood increase happiness? Evidence for Poland
}

\author{
Anna Baranowska and Anna Matysiak*
}

\begin{abstract}
In the recent decade demographers turned their attention to investigating the effects of children on self-rated happiness or life satisfaction. The underlying idea of this strand of research is to find out whether it pays off for individuals to become parents in terms of their subjective well-being, given the costs of having children. Following this line of research, this article studies the impacts of childbearing on individual-level happiness in Poland; a country which experienced a rapid decline in fertility despite the particularly strong attachment of young Poles to family values. To this end, we applied methods for panel data analysis which allowed us to control for endogeneity of subjective well-being and parenthood. Our results reveal a significantly positive effect of the first child on the subjective well-being of mothers. For men, this impact is weaker and most likely temporary since it weakens with the child's increasing age. An important finding is that neither for men nor for women does the positive impact of parenthood rise with an increase in parity. This may explain the persistence of low fertility in this country.
\end{abstract}

\section{Introduction}

Why do some people decide to have fewer children than others and what are the motives for having children later in life? Demographers have been struggling to answer these questions as fertility in Europe has declined below replacement levels and couples have been postponing their childbearing decisions to even later stages in life. These questions gained additional interest after clear cross-country differences in fertility levels became visible, with some countries displaying birth rates close to replacement levels and others exhibiting very low fertility. Most

\footnotetext{
* Anna Baranowska (correspondence author), Institute of Statistics and Demography, Warsaw School of Economics, Ul. Madalińskiego 6/8, 02-513, Poland. Email: anna.baranowska@sgh.waw.pl

Anna Matysiak, Institute of Statistics and Demography, Warsaw School of Economics, Poland. Email: amatys@sgh.waw.pl
} 
explanations of these phenomena refer to an increase in the opportunity costs of children. It was argued that having children early in life as well as having a larger number of children may substantially affect women's wages as well as jeopardise their employment prospects (Gustafsson 2001; Hotz et al. 1997; Taniguchi 1999). The opportunity costs of children were claimed to be particularly high in countries with low support to working parents (Rindfuss et al. 2003; Engelhardt et al. 2004) and rigid labour markets (Ahn and Mira 2002; Adsera 2005). Additionally, the proponents of the Second Demographic Transition theory indicated that indirect costs of children might have increased as women became more interested in pursuing professional careers (Van de Kaa 1988; Lesthaeghe 1995).

Given these arguments on the rising costs of children a question has emerged whether it pays off for individuals to have children at all. This turned the attention of demographers to investigating the effects of children on the subjective wellbeing of individuals (e.g. Kohler et al 2005; Billari and Kohler 2009; Aassve et al 2009; Margolis and Myrskylä 2010). Does the entry to parenthood increase individual happiness? Is one child sufficient to satisfy the parents' emotional needs or does an increase in family size beyond parity one bring further gains in terms of happiness and satisfaction with life? These and similar questions have been asked in order to better understand the macro-level fertility levels.

Following this newly emerging line of research on the impact of parenthood on subjective well-being, in this article we investigate the effects of children on self-rated happiness among the Poles. Poland is an interesting case study for this research purpose as it has displayed a very low fertility (Total Fertility Rate below 1.4) for over one decade despite the extraordinarily strong attachment of its citizens to family values. Persistently low fertility in Poland has been widely explained by the high opportunity costs of children, resulting from strong tensions between work and family tied up with strong unemployment pressure and high instability of employment contracts (Kotowska 1999; Kotowska et al. 2008; Mynarska 2011). Indeed, a glance at macro-level indicators confirms that among the EU Member States, Poland in the 2000s displayed one of the strongest incompatibilities between work and care (Matysiak 2011, p. 85), relatively high unemployment levels among the youth and a high temporary employment rate (Baranowska and Gebel 2010). Given these unfavourable conditions for family formation coupled with the strong attachment of Poles to family values it is interesting to verify whether parenthood brings parents any gains in terms of wellbeing.

The article starts with theoretical considerations that lie behind the idea of investigating the effects of parenthood on subjective well-being. In the following section we review the available empirical studies on this topic and move on to describing the context of Poland in which fertility decisions are made. Subsequently, we present our data and analytical strategy and describe our 
empirical findings. The article closes with a short summary of our major results and suggestions for further research.

\section{Theoretical background}

Demographic theories trying to explain childbearing decisions usually refer to benefits and costs of having children. Various benefits from having children have been named in the literature. In the field of economics originally three types of benefits, or - in economic terms - utilities, were recognised: a work or income utility, assuming that children provide labour in a family business or a farm, a security utility, given that children may serve as an insurance and social protection to their parents in the old age, and a consumer utility, referring purely to emotional benefits (Leibenstein 1957). A similar approach was adopted in the psychological literature. The proponents of the Value-of-Children theory also argued that people decide to have children since parenthood is associated with a range of positive values. Apart from the economic and security benefits they enumerated a whole variety of other values, such as an increase in parents' social status, strengthening of their social ties, ability to enjoy novelty and a sense of achievement in their lives (Hoffman and Hoffman 1973). Positive aspects of parenthood were also underlined in evolutionary theories, which posit that humans have evolved a predisposition towards nurturing (Foster 2000; Rodgers et al. 2001). From this perspective, parents can enjoy taking care and fostering the intellectual and physical development of children. Finally, it is to be noted that benefits from children depend on parity and country-specific contexts. The study by Bulatao (1981) showed that parents value their first child mainly because of the emotional benefits. The decision to have the second or third child is driven by a need to satisfy other needs, i.e. the desire to ensure a companion for the first child or to achieve a certain sex composition of children. The values attached to higher-order births are often economic. These differences in the values attached to children by parity were also used by Bulatao (1981) to explain fertility differences across countries varying in the levels of economic development as well as in the advancement of social security systems.

Despite the fact that children bring certain benefits to their parents they also imply costs. First of all, raising children requires financial expenditures. Second, it imposes indirect costs, particularly on the parent who withdraws from employment to provide care. These costs include not only the income lost during the non-participation period, but also non-accumulation and depreciation of human capital as well as lost promotion opportunities (Becker 1993; Even 1987; Joesch 1994; Ranson 1998). Furthermore, parenthood may also result in emotional distress (McLanahan and Adams 1987) as it leads to an increase in time conflict and poses additional strain on parents (Pailhé and Solaz 2009), imposes greater financial responsibilities (Zimmerman and Easterlin 2006; Stanca 2009), 
reduces time spent on leisure (Sanchez and Thomson 1997) and may even negatively affect the quality of the relationship between parents (Lavee et al. 1996). The costs of children are likely to be higher for parents with a larger family size as well as for parents with small children. Infants or toddlers require more intense care than school-age children. Besides, the early years of rapid child's development are a critical period, and the awareness of this fact might additionally raise the stress experienced by young parents (Gordon and Gluzman 2007). Finally, the costs of children vary depending on the country-specific context. It has been widely argued that opportunity costs are higher in countries with rigid working hours and a strong insider-outsider divide, as well as in countries that lack safety nets and public support to working parents (Adsera 2005; Esping-Andersen 1999; Rindfuss et al 2003; Muszyńska 2007).

Taking together the benefits and costs of children the question emerges as to what is the net gain for parents from having children. Do children increase the well-being of couples? Are persons who have a child more happy or satisfied with life than those who do not despite the costs the former have to bear? And to what extent does the happiness of parents depend on their parity? Does it change in a similar way with each additional child or does the effect of children on happiness depend on the parity? Answering these questions could help us in understanding the current fertility levels in Europe.

\section{Review of empirical research}

Although investigating the effect of children on parents' subjective well-being seems to be a natural first step to understand current fertility levels in Europe, the empirical evidence on this topic is very scarce. One of the reasons for this state of affairs is related to the measurement of well-being. Large-scale surveys usually implement a single item on happiness or life satisfaction and one may doubt whether an answer to such a question provides a reliable assessment of the subjective well-being. This issue has been extensively studied, however, and recent studies confirm the relevance of measuring self-rated happiness by means of direct single-item survey questions (Stutzer and Frey 2006; Easterlin 2004). ${ }^{1}$ However, studying the effects of parenthood on happiness requires sophisticated analytical methods. The difficulty lies in arising selection problems as some of the unobserved individual characteristics such as extraversion or neuroticism may have an impact on self-rated happiness and simultaneously affect decisions about family formation (Costa and McCrae 1980; Tavares 2008). Hence, systematic differences in the personality of parents and non-parents may lead to endogeneity bias in any cross-sectional estimates.

Obviously, including a whole battery of questions on subjective well-being ensures greater reliability of the dependent variable, but at a high cost, which cannot be accepted in most largescale surveys. 
To our best knowledge, there have been only few articles so far that demonstrated the effects of parenthood on well-being net of selection effects, and the evidence is very mixed. Clark et al. (2008) used fixed-effects models on data from the German Socio-Economic Panel to show that the arrival of a child increases the mother's happiness but causes no significant effect on the father's life satisfaction. ${ }^{2}$ Interestingly, these effects also vary over the age of the child: by the time the child is $2-3$ years old, the impact of having a child turns negative for both sexes and remains so thereafter. Kohler et al. (2005) used fixed-effects models on Danish sibling data to show a diverging impact of childrearing depending on gender and parity. The authors revealed that the first-born child had a large positive effect on the well-being of young females. However, a second child decreases happiness, and having three or more additional children almost completely cancels the positive effect that resulted from having the first child. For men, an increase in happiness resulting from the first child is weaker than for women, but males do not experience as strong declines in happiness with additional children as females do. Finally, Angeles (2009a; 2009b) using data from the British Household Panel Study found no statistically significant effect of children on the satisfaction with life of married individuals.

Some attempts have also been made in the literature to assess the role of the country context for mediating the effect of children on parents' well-being. These studies aimed at testing the hypothesis that gains in happiness brought by children are stronger in countries where the opportunity costs of childbearing are lower. Among the most recent contributions, Margolis and Myrskylä (2010) found that the context plays an important role in explaining the happiness-fertility association. This association among young persons was established to be negative, but its magnitude was weakest in countries with high public support for families. A contradictory finding was established by Aassve et al. (2009), however, who found the relationship to be positive, but recognised no clear-cut pattern across countries. Nonetheless, these two studies are based on crosssectional data and hence provide us with information on associations rather than on causal effects as individual differences in biological or social endowments are not taken into account.

The potential usefulness of research on the effect of children on happiness and the scarce evidence obtained so far call for further investigations on the topic. Rising to this challenge in our article, we study the impact of parenthood on subjective well-being in Poland, a country characterised by high opportunity costs of childbearing but at the same time by a strong attachment to family values.

The authors did not analyse in detail whether the magnitude of the effect of childbearing depends on the parity. 


\section{Polish context}

Various surveys have constantly pointed out that family and children take an important position in the value system of the Poles. For instance, the data from the International Population Policy Acceptance Study (IPPAS) clearly show that Poles, together with Lithuanians and Hungarians, set an exceptionally high priority on marriage, strongly oppose the de-institutionalisation of the family and relatively often express the belief that children, family and the home ensure happiness and self-fulfilment (Pongracz and Spéder 2008; Stankuniene and Maslauskaite 2008). These findings are further corroborated by the data from the European Value Study, which showed that in 1999 family was viewed as an important life sphere by $91 \%$ of Polish respondents, whereas in other countries these percentages were substantially lower: on average $79 \%$ in post-socialist region, $83 \%$ in non-Catholic Western countries and $87 \%$ in Roman-Catholic ones (Giza-Poleszczuk and Poleszczuk 2004, p. 207).

Despite this strong attachment of the Poles to family and children, the fertility decline in Poland was by no means smaller than in any other post-socialist country. Over the 14 years of economic transformation the period TFR dropped from 2.09 in 1989 to its minimum of 1.22 in 2003, placing Poland among the lowest-low fertility countries. The decline in period fertility was partly driven by the postponement of births and partly by a fall in fertility quantum (Sobotka et al. 2005). Second- and higher-order fertility rates decreased most strongly. Nonetheless, Poland also experienced a decline in first-order fertility and a pronounced increase in childlessness: whereas among women born in 1960 only $10 \%$ were childless, among the 1970 cohort it was already $15 \%$, which was the highest level among the central and eastern European countries (Frejka 2008). Only since the mid-2000s has Poland been experiencing a slight improvement in fertility with period TFR increasing to 1.39 by 2009. Despite this upward trend the country remains one of the lowest-fertility countries in the EU.

This dramatic decline in fertility and the persistence of childbearing rates at very low levels have been often explained in the literature by changes in the conditions of labour force participation, the state's withdrawal from public support for working parents and consequently a strong increase in the opportunity costs of parenting (Kotowska and Sztanderska 2007; Kotowska et al. 2008; Frejka 2008). As a result, Poland belongs to the group of countries characterised by the strongest incompatibilities between women's employment and childrearing (Matysiak 2011, p. 85). Public provision of child care is the worst in the whole EU. In the 2000s the coverage rate in crèches amounted to 24 places per 1000 children aged 3 or less. The situation in nursery schools was better - around 600 places per 1000 children in pre-school age - but still Poland takes the last position in this respect among the EU Member States. Poor child care provision is compensated by long - up to three years - parental leaves. These leaves are unpaid, however, except for mothers in a very poor financial position. Polish 
women rarely take advantage of full provisions but return to work instead (Matysiak and Vignoli 2010). Furthermore, the fathers' involvement in child care has hardly been facilitated by public policies - until 2010 there were no statutory paternity leaves and only 2.5\% of fathers made use of parental leaves (Matysiak 2007). The high opportunity costs of childbearing in Poland were further exacerbated by strong unemployment pressure, reflected in high unemployment rates of young people and high instability of employment contracts, as well as by scarcity of part-time jobs and a high degree of rigidity in working hours (Kotowska et al. 2008).

Taking into account the high indirect costs of childbearing, one may ask whether it pays off for the Poles in terms of their subjective well-being to become parents as well as to extend their family size beyond parity one. It is likely that the high costs of children exceed the benefits and despite their strong attachment to family values, the Poles abandon the idea to have large families. Instead they decide for one child only, which may be sufficient for satisfying their emotional needs. These hypotheses with regard to persons in reproductive age are addressed in the following sections of this article.

\section{Data and method}

\subsection{Data}

The data used in this study come from Social Diagnosis, a national representative longitudinal survey established by the Council of Social Monitoring in 2000. Subsequent waves took place in 2003, 2005, 2007 and 2009. It represents a unique source of panel micro-data in Poland, covering information from a variety of areas, such as household income and living conditions, education and labour market participation as well as health and subjective well-being of household members. Altogether, in all five waves, 38,731 face-to-face interviews were conducted with household members aged 16 or more (Czapiński and Panek 2009). To the best of our knowledge, it is probably the largest and most comprehensive panel survey carried out in central and eastern Europe that includes questions on happiness (Randall and Hanousek 2002). For our analysis we selected persons who entered the survey at age 18-35, i.e. in their childbearing and childrearing age. This gave us a sample of 6513 female and 5870 male observations.

Our dependent variable, i.e. the level of happiness, is derived from a singleitem question: "Taking all things together, would you say you are very happy, quite happy, somewhat happy or not at all happy?", with responses coded on a four-point scale. In the context of this study this measure has the advantage of brevity. It was adapted from the World Value Survey, and a similar question is also included in other large cross-national or country-specific surveys. Table 1 
presents the distribution of this variable in the samples of men and women selected for our analyses.

Table 1:

Distribution of variable measuring subjective well-being in Social Diagnosis 20032009, men and women aged 18-35 at first interview

\begin{tabular}{lcc|cc}
\hline & \multicolumn{2}{c|}{ Women } & \multicolumn{2}{c}{ Men } \\
\hline Response & $\begin{array}{c}\text { Number of } \\
\text { observations }\end{array}$ & $\begin{array}{c}\text { Percentage of } \\
\text { pooled sample }\end{array}$ & $\begin{array}{c}\text { Number of } \\
\text { observations }\end{array}$ & $\begin{array}{c}\text { Percentage of } \\
\text { pooled sample }\end{array}$ \\
\hline not at all happy & 95 & 1.46 & 93 & 1.59 \\
somewhat happy & 1,114 & 17.12 & 1,131 & 19.29 \\
quite happy & 4,614 & 70.91 & 4,083 & 69.65 \\
very happy & 684 & 10.51 & 555 & 9.47 \\
\hline Total & 6,507 & 100 & 5,862 & 100 \\
\hline
\end{tabular}

Source: author's own calculations on the basis of pooled data from Social Diagnosis 2003-2009.

Table 2:

Descriptive statistics on pooled sample data, men and women aged 18-35 at first interview

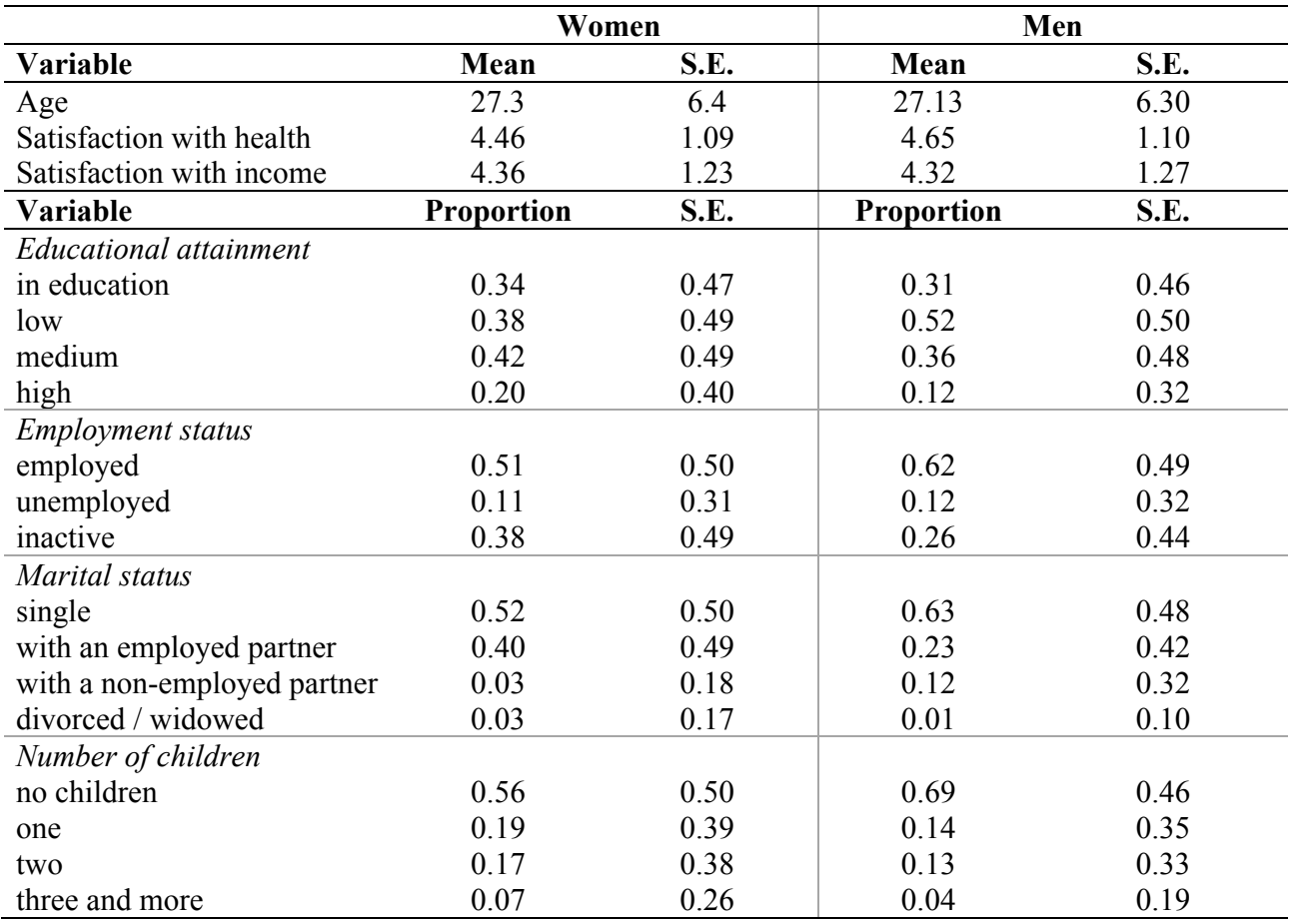

Source: authors' estimates based on Social Diagnosis 2003-2009 
Our key explanatory variables were the number of children of respondents and the age of their youngest child. Our sample covers 217 transitions to first birth, 178 transitions to second birth and 91 transitions to third or higher-order child. Additionally, we included specifications where we accounted for the age of the youngest child. Our results are standardised for a set of observed personspecific characteristics, such as: respondent's age and age square, educational attainment (including participation in education), self-rated health, self-rated material standard of living, marital status and labour market status of the respondent and his or her partner.

\subsection{Econometric specification}

We modelled the respondents' self-rated happiness at any point in time $t$ as a function of our key explanatory variables (children) at time $t$, a set of the observed individual-level characteristics measured in the survey at time $t$ (obs_characteristics), as well as unobserved individual time-invariant traits $\mathrm{u}_{\mathrm{i}}$. Additionally, respondents' subjective well-being was subject to random error $\varepsilon_{\text {it, }}$, which may capture random, idiosyncratic influences such as good weather on the day of interview or an exceptionally good mood of the respondent. Hence, the model can be written in the following way:

$$
\text { happiness }_{i t}=\beta_{0}+\beta_{1} \times \text { children }_{t}+\beta_{2} \times \text { obs_characteristics }_{i t}+u_{i}+\varepsilon_{i t}
$$

The most common approach to controlling for individual-specific timeinvariant unobserved characteristics with panel data at hand is to estimate fixedeffects models. Fixed-effects estimates are based on the variation of respondents' characteristics across time by contrast to random-effects models that also use variation across individuals. Fixed-effects estimates are therefore less efficient than random-effects estimates but remove the potential bias resulting from the selection of "intrinsically (un)happy" individuals into the group of parents by allowing for a correlation between the person-specific unobserved time-invariant characteristics and the regressors. The disadvantage of the fixed-effects approach is that it can easily be implemented in the linear regression framework, but accommodating it to models with dependent variables measured on an ordinal scale is more problematic. In some situations, if the scale of the dependent ordinal variable is relatively long and approximates interval data, linear regression may yield similar results as ordered probit or logit regression (Ferrer-i-Carbonell and Frijters 2004). However, in our case the dependent variable has only four categories and so using the linear specification, which requires the cardinality assumption, ${ }^{3}$ is questionable since it might severely bias our estimates (for the discussion on the topic see Baetschmann et al. 2011; Geishecker and Riedl 2010). The simplest alternative approach to this problem is to recode the ordinal

\footnotetext{
The cardinality assumption implies that the intervals between the categories of the dependent variable are equal.
} 
dependent variable into a binary indicator and subsequently apply the conditional logit estimator proposed by Chamberlain (1980). Dichotomisation has two certain drawbacks, however. First, it requires an arbitrary assumption, i.e. a choice of a threshold above which the dependent binary variable takes the value one. Second, it implies a loss of a great deal of information. In this article we employed two other solutions that allowed us to account for unobserved characteristics of individuals. The first approach was to use a "Blow-up and Cluster" (BUC) estimator developed by Baetschmann et al. (2011). This estimator extends the idea of dichotomisation proposed by Chamberlain (1980). More specifically, it dichotomises the dependent variable in all possible cut-off points and performs a joint estimation of the resulting fixed-effects logits. It was selected for the purpose of this study as it was shown to provide robust estimates on panel data with a small number of waves (see Baetschmann et al. (2011) for evidence). ${ }^{4}$ Our second approach was to estimate a correlated random-effects model which draws on the approach proposed by Mundlak (1978). This method decomposes the unobserved time-constant individual effect $u_{i}$ into a random effect $\eta_{i}$ which is uncorrelated with the explanatory variables and the mean values of the timevarying regressors that are expected to be correlated with the individual random effects (Mundlak 1978). Referring to our research problem the unobserved timeconstant individual effect is specified as:

$$
u_{i}=\gamma_{1} \times \overline{\text { obs_characteristics }}_{i}+\gamma_{2} \times \overline{\text { children }}+\eta_{i}
$$

The distribution of $\eta_{i}$ is assumed to be normal with a mean equal to zero and a constant variance, conditional on the mean individual characteristics over time. The parameters $\gamma_{1}$ and $\gamma_{2}$ are meant to pick up the correlation between the covariates and the person-specific time-invariant unobserved characteristics. The specified correlated random-effects model not only accounts for selection effects, but it also has certain advantages over fixed-effects models. First, it produces more efficient estimates. Second, it was shown to perform better in the panel data setup with relatively few waves. While fixed-effects models estimated on data with a small number of waves may lead to incidental parameters problem, correlated random-effects models avoid this kind of pitfall (Chamberlain 1980).

\section{Empirical findings}

We estimated our models separately for men and women in order to take into account the possibility that costs of and benefits from children may be different for mothers and for fathers. The results of the correlated random effects model and the model using the BUC estimator are presented in Tables $3 \mathrm{a}$ and $3 \mathrm{~b}$. In some cases, the correlated random effects model yields more significant estimates

\footnotetext{
In that respect it is superior over alternative estimators, such as estimators developed by Ferreri-Carbonell and Frijters (2004) or Das and Van Soest (1999).
} 
than the BUC model which is consistent with the fact that estimates from randomeffects models are more efficient than those from fixed-effects models.

The effects of most of our control variables are similar to the effects observed in other studies on subjective well-being. The self-rated happiness seems to vary across age and education, although these influences turn out to be insignificant in the fixed-effects model with BUC approach. Both models reveal significant effect of self-rated satisfaction with the state of own health and the financial situation of one's household on respondent's happiness. Both for men and women, entry into unemployment means a significant decline in subjective well-being (although for women this effect appears insignificant in the model using the BUC estimator). Neither the fact of marrying nor the employment situation of the spouse influence self-rated happiness. Losing a partner due to divorce or widowhood lowers the subjective well-being of women, though this has no impact on men.

Table 3a:

The determinants of happiness among women

\begin{tabular}{|c|c|c|c|c|c|c|}
\hline & \multicolumn{3}{|c|}{ Correlated RE model } & \multicolumn{3}{|c|}{ BUC estimator } \\
\hline & coef. & & s.e. & coef. & & s.e. \\
\hline age & 0.069 & $* *$ & 0.034 & 0.162 & & 0.153 \\
\hline age squared & -0.001 & $* *$ & 0.001 & -0.002 & & 0.002 \\
\hline \multicolumn{7}{|l|}{ Education (low = ref.) } \\
\hline in education & 0.022 & & 0.096 & 0.079 & & 0.205 \\
\hline medium & 0.215 & $* *$ & 0.099 & 0.300 & & 0.223 \\
\hline high & 0.250 & & 0.174 & 0.276 & & 0.377 \\
\hline satisfaction with health & 0.235 & $* * *$ & 0.029 & 0.442 & $* * *$ & 0.063 \\
\hline satisfaction with income & 0.422 & $* * *$ & 0.028 & 0.815 & $* * *$ & 0.065 \\
\hline \multicolumn{7}{|c|}{ Labour market status (employed = ref.) } \\
\hline unemployed & -0.170 & + & 0.096 & -0.237 & & 0.202 \\
\hline inactive & -0.121 & & 0.083 & -0.193 & & 0.178 \\
\hline \multicolumn{7}{|c|}{ Partner and his labour market status (single $=$ ref.) } \\
\hline with an employed spouse & 0.108 & & 0.144 & 0.016 & & 0.272 \\
\hline with a non-employed spouse & -0.030 & & 0.184 & -0.082 & & 0.378 \\
\hline divorced / widowed & -0.630 & $* *$ & 0.260 & -1.219 & $* *$ & 0.520 \\
\hline \multicolumn{7}{|l|}{ Children (no children $=$ ref. $)$} \\
\hline one & 0.374 & $* *$ & 0.157 & 0.617 & + & 0.342 \\
\hline two & 0.337 & + & 0.204 & 0.542 & & 0.485 \\
\hline three or more & 0.449 & & 0.301 & 0.473 & & 0.649 \\
\hline (youngest) child over 1 year old & -0.121 & & 0.080 & -0.131 & & 0.236 \\
\hline LL & \multicolumn{3}{|c|}{-4505.922} & \multicolumn{3}{|c|}{-536.386} \\
\hline $\mathrm{N}$ & \multicolumn{3}{|c|}{6513} & \multicolumn{3}{|c|}{2379} \\
\hline
\end{tabular}

Source: authors' estimates based on Social Diagnosis, Significance levels: $+\mathrm{p}<.1,{ }^{* *} \mathrm{p}<.05,{ }^{* *} \mathrm{p}<.01$

Parenthood turns out to be an important determinant of happiness for women, but not so much for men. Its effect clearly depends on parity. Both model specifications show that the arrival of the first child causes an increase in the well-being of new mothers. The effects of second or higher-order births are already more ambiguous. The correlated random-effects model suggests that 
women with two children are also significantly happier than childless ones; on the other hand, the birth of the second child does not increase the subjective wellbeing of women compared to one-child mothers. The effect of third or higherorder birth in this model is already insignificant although it is large and positive. So are the effects of second or higher-order children in the BUC model. These results suggest that increasing their family size beyond parity one does not further affect the subjective well-being of mothers. Furthermore, we find no effect of the child's age on women's subjective well-being.

Table 3b:

The determinants of happiness among men

\begin{tabular}{|c|c|c|c|c|c|c|}
\hline & \multicolumn{3}{|c|}{ Correlated RE model } & \multicolumn{3}{|c|}{ BUC estimator } \\
\hline & coef. & & s.e. & coef. & & s.e. \\
\hline age & -0.038 & & 0.037 & -0.267 & + & -0.038 \\
\hline age squared & 0.001 & & 0.001 & 0.007 & $* *$ & 0.001 \\
\hline \multicolumn{7}{|l|}{ Education $($ low $=$ ref. $)$} \\
\hline in education & 0.028 & & 0.110 & 0.201 & & 0.028 \\
\hline medium & 0.115 & & 0.112 & 0.209 & & 0.115 \\
\hline high & 0.234 & & 0.228 & 0.337 & & 0.234 \\
\hline satisfaction with health & 0.163 & $* * *$ & 0.030 & 0.300 & $* * *$ & 0.163 \\
\hline satisfaction with income & 0.438 & $* * *$ & 0.028 & 0.749 & $* * *$ & 0.438 \\
\hline \multicolumn{7}{|c|}{ Labour market status (employed $=$ ref.) } \\
\hline unemployed & -0.342 & $* * *$ & 0.098 & -0.584 & $* * *$ & -0.342 \\
\hline inactive & -0.046 & & 0.105 & -0.123 & & -0.046 \\
\hline \multicolumn{7}{|c|}{ Partner and his labour market status (single $=$ ref.) } \\
\hline with an employed partner & 0.059 & & 0.164 & -0.089 & & 0.059 \\
\hline with a non-employed partner & 0.061 & & 0.182 & 0.173 & & 0.061 \\
\hline divorced / widowed & 0.078 & & 0.415 & 0.148 & & 0.078 \\
\hline \multicolumn{7}{|l|}{ Children (no children $=$ ref.) } \\
\hline one & 0.514 & $* *$ & 0.203 & 0.682 & & 0.514 \\
\hline two & 0.399 & & 0.247 & 0.284 & & 0.399 \\
\hline three or more & 0.444 & & 0.359 & 0.021 & & 0.444 \\
\hline (youngest) child over 1 year old & -0.364 & $* * *$ & 0.095 & -0.723 & + & -0.364 \\
\hline LL & & -4497 & & & -53 & 8.648 \\
\hline $\mathrm{N}$ & & 58 & & & & 986 \\
\hline
\end{tabular}

Source: authors's estimates based on Social Diagnosis, Significance levels: $+\mathrm{p}<.05, * * \mathrm{p}<.01, * * * \mathrm{p}<.001$

For men, the effects of children on subjective well-being are much weaker, which is consistent with available empirical research for other countries. More specifically, the first child raises men's subjective well-being only in the correlated random-effects model, but the same model suggests that the increase in fathers' happiness is temporary and falls substantially as the child becomes one year and older. When measured by means of a fixed-effects model with the BUC approach, the effects of the number of children as well as the age of the youngest child appear strong but the standard errors of these estimates are very large and the overall effect turns out insignificant. 
In order to better illustrate the magnitude of the impact of childbearing on happiness, we present the marginal effects of this variable on Figures 1a and $1 \mathrm{~b}$. The marginal effects were estimated based on the correlated random-effects model, because only this model allows for a meaningful interpretation of the results. ${ }^{5}$ They show a change in the probability of describing oneself as "very happy" after a change in the number of children or the age of the youngest child. Four situations were considered: 1) a parent of one child aged less than one year, 2) a parent of one child aged over one year, 3) a parent of two children with the youngest aged less than one year, and 4) a parent of three children with the youngest aged less than one year. The marginal effects were estimated for a reference person aged 27 who completed upper secondary education, is satisfied with his/her health and quite satisfied with his/her living standards, employed, with a working partner and with no children.

Focusing on women, we can see that the arrival of a first child substantially increases happiness: the probability of being very happy jumps by 9.1 percentage points (Figure 1a). As the first child ages, the marginal effect of having this child on happiness decreases, although the model estimates presented in Table 3a suggest this decline is insignificant. Interestingly, the second child does not bring an additional significant increase in happiness. Women who give birth to a second child are significantly more likely to be very happy (by 8.1 percentage points) than childless ones but they do not differ much in that respect from one-child mothers. Caution is needed, however, when interpreting the predicted probabilities of being very happy for women with two children as the BUC model demonstrated the estimates of the gains in happiness for these women to be less robust (see Table 3a). While the increase in happiness among women who enter motherhood is evident, the results on the benefits of having the second child are less clear. The effect of an arrival of third and subsequent children seems to be even less robust. The gain in happiness after the third child seems positive rather than negative, but the standard errors of this estimate are substantial.

A similar pattern of the influence of parenthood on happiness can be observed among men, only that the general gain in happiness derived from parenthood is even smaller than for women, and according to the BUC model even insignificant. After the arrival of a first child, the probability of being very happy rises by 5.8 percentage points (Figure 1b). As the child grows up, its effect on happiness declines - the probability that a father with one child older than one year describes himself as very happy is only 1 percentage point higher than for childless men. The arrival of a second and third child causes an increase of happiness of about 4.1 and 4.7 percentage points, respectively, compared to childless men. Hence, similarly to the case of women, our results show that entry into fatherhood increases happiness (although the magnitude of this effect is far

Marginal effects show a change in the dependent variable after a change in one (or more) of the explanatory variables. 
weaker), but higher-order births seem to evoke negligible effects on self-rated happiness among men.

Figure 1a:

Marginal effects of the arrival of a child of specific parity on indicating being 'very happy' among women

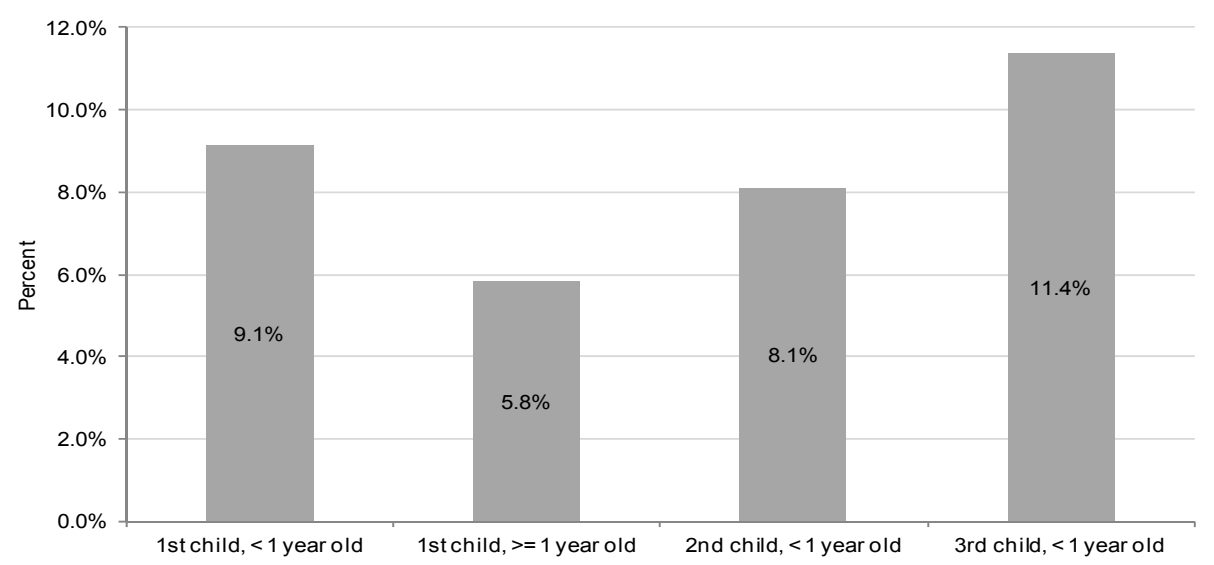

Source: authors' estimates based on Social Diagnosis. The reference category are childless women

Figure 1b:

Marginal effects of the arrival of a child of specific parity on indicating being 'very happy' among men

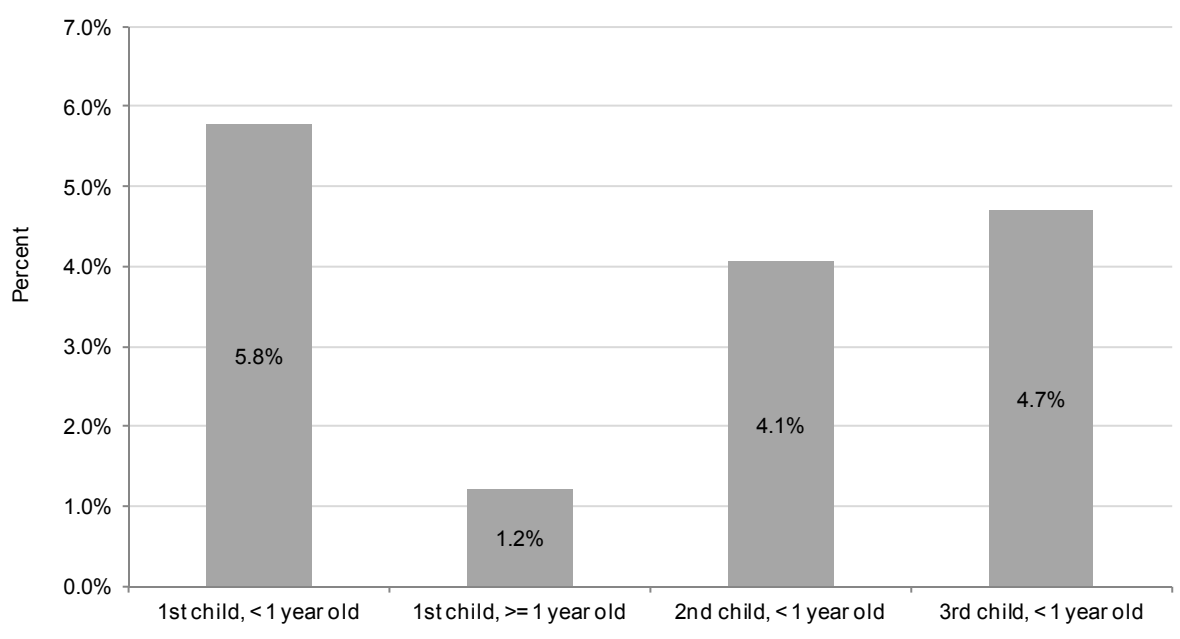

Source: authors' estimates based on Social Diagnosis. The reference category are childless men 


\section{Conclusions}

In this article we presented empirical findings on the effects of parenthood on self-rated happiness among people of reproductive age in Poland. We used methods that allow to remove the bias resulting from the selection of "intrinsically (un)happy" individuals into parenthood. Our results reveal a significantly positive effect of the first child on the subjective well-being of mothers. For men, this impact is weaker, somewhat less clear-cut and most likely of temporary nature (it weakens with an increase in child's age). However, neither for men nor for women does the positive impact of parenthood rise with an increase in parity. In other words, entry to parenthood leads to gains in happiness but extending the family size beyond parity one does not bring any further significant pay-off in terms of happiness. At this point it should be noted, however, that our estimates of the effects of second and higher-order births compared to childless people were positive but also displayed high standard errors. This may result from the low number of panel waves we had at our disposal as well as from the low number of transitions to second and higher-order births. Hence, the effect of increasing the family size beyond parity one requires a more in-depth investigation in future research, possibly using longer panel data.

This finding might explain the persistence of low fertility in Poland in the recent decade. Despite the strong attachment of Poles to family values, the net effect of having a child on the individual well-being seems strong and positive only in case of first birth. There are at least two possible and nonexclusive explanations for this pattern. First, given the theoretical findings of Bulatao (1980), the first child might be enough to satisfy the emotional needs of parents, and the additional benefits from higher-order births might be lower, compared to those brought by the first child. Second, every subsequent child might bring the same benefits to parents, but the costs of rearing children might be increasing with parity in a disproportional way. This might be the case particularly in a country like Poland where the opportunity costs of childbearing are very high. Further comparative research on the impact of parenthood on the subjective wellbeing in countries that vary in opportunity costs of children is required, however, in order to corroborate our conclusion. Finally, it is desirable to look more closely into the benefits children bring to parents independently of their costs in order to better understand the role of these two factors for fertility decisions.

\section{Acknowledgements}

This article was prepared within the research project "Family Change and Subjective Well-Being" (FAMWELL) financed by the National Centre for Research and Development, under the Lider programme. We would like to thank Monika Mynarska, Marta Styrc and the two anonymous reviewers of the journal 
for their helpful comments and Mark Bryan for his methodological suggestions. We are also grateful to the participants of the conference „From Intentions to Behaviour: Reproductive Decision-Making in a Macro-Micro Perspective", organised by VID in 2010, for their feedback.

\section{References}

Aassve, A., A. Goisis and M. Sironi 2009. Happiness and childbearing across Europe. Dondena Centre for Research on Social Dynamics Working Paper 1977(10). Milano: Bocconi University.

Adsera, A. 2005. Vanishing children: from high unemployment to low fertility in developed countries. The American Economic Review 95(2): 189-193.

Ahn, N. and P. Mira 2002. A note on the changing relationship between fertility and female employment rates in developed countries. Journal of Population Economics 15(4): 667-682.

Angeles, L. 2009a. Children and life satisfaction. Journal of Happiness Studies 11(4): 523-538.

Angeles, L. 2009b. Erratum to children and life satisfaction. Journal of Happiness Studies 11(4): 523-538.

Baetschmann, G., K.E. Staub and R. Winkelmann 2001. Consistent estimation of the fixed effects ordered Logit model. IZA Discussion Paper 5443. Bonn: Institute for the Study of Labor (IZA).

Baranowska, A. and M. Gebel 2010. The determinants of youth temporary employment in the enlarged Europe. Do labour market institutions matter? European Societies 12(3): 367-390.

Becker, G.S. 1993. A treatise on the family. London: Harvard University Press.

Billari, F.C. and H.P. Kohler 2009. Fertility and happiness in the XXI century: institutions, preferences, and their interactions. Paper presented at annual meeting of the Population Association of America, Detroit, April 2009.

Bulatao, R.A. 1981. Values and disvalues of children in successive childbearing decisions. Demography 18(1): 1-25.

Chamberlain G. 1980. Analysis of covariance with qualitative data. The Review of Economic Studies 47(1): 225-238.

Clark, A.E., E. Diener, Y. Georgellis and R.E. Lucas 2008. Lags and leads in life satisfaction: a test of the baseline hypothesis. The Economic Journal 118(529): F222-F243.

Costa, P.T. and R.R. McCrae 1980. Influence of extraversion and neuroticism on subjective well-being: happy and unhappy people. Journal of Personality and Social Psychology 38(4): 668-678.

Czapiński, J. and T. Panek 2009. Diagnoza Społeczna 2009. Warunki i jakość życia Polaków. Warsaw: Rada Monitoringu Społecznego.

Das, M. and A. van Soest 1999. A panel data model for subjective information on household income growth. Journal of Economic Behavior and Organization 40: 409-26.

Easterlin, R. 2004. The economics of happiness. Daedalus 133(2): 26-33. 
Engelhardt, H., T. Kögel, and A. Prskawetz 2004. Fertility and women's employment reconsidered: a macro-level time-series analysis for developed countries, 1960-2000. Population Studies 58(1): 109-120.

Esping-Andersen, G. 1999. Social foundations of postindustrial economies. Oxford: Oxford University Press.

Even, W.E. 1987. Career interruptions following childbirth. Journal of Labor Economics 5(2): 255-277.

Ferrer-i-Carbonell, A. and P. Frijters 2004. How important is methodology for the estimates of the determinants of happiness? The Economic Journal 114(497): 641-659.

Foster, C. 2000. The limits to low fertility: a biosocial approach. Population and Development Review 26(2): 209-234.

Frejka, T. 2008. Determinants of family formation and childbearing during the societal transition in Central and Eastern Europe. Demographic Research 19(7): 139-170.

Geishecker, I. and M. Riedl 2010. Ordered response models and non-random personality traits: Monte Carlo simulations and a practical guide. Center for European Governance and Economic Development Research Discussion Paper 116.

Giza-Poleszczuk, A. and J. Poleszczuk 2004. Partnership, marriage, and children - cultural differentiation of attitudes. In Poles among Europeans, ed. A. Jasińska-Kania and M. Marody. Warsaw: Scholar.

Gordon R.A. and A. Gluzman 2007. Why those baby blues? Change in strain from child care arrangements and in depression among employed mothers of young children. Paper prepared for the conference of the ISA Research Committee on Social Stratification and Mobility, Montreal, 14-17 August 2007.

Gustafsson, S. 2001. Optimal age at motherhood. Theoretical and empirical considerations on postponement of maternity in Europe. Journal of Population Economics 14(2): 225-247.

Hoffman, L.W. and M.L. Hoffman 1973. The value of children to parents. In Psychological Perspectives on Population, ed. J. T. Fawcett, 19-76. New York: Basic Books.

Hotz, V.J., J.A. Klerman and R.J. Willis 1997. The economics of fertility in developed countries. In Handbook of population and family economics, ed. M.R. Rosenzweig and O. Stark, 275-347. Amsterdam: Elsevier.

Joesch, J.M. 1994. Children and the timing of women's paid work after childbirth: a further specification of the relationship. Journal of Marriage and the Family 56(2): 429-440.

Kohler, H.-P., J.R. Behrman and A. Skytthe 2005. Partner + children = happiness? An assessment of the effect of fertility and partnerships on subjective well-being in Danish twins. Population and Development Review 31(3): 407-445.

Kotowska, I.E. 1999. Drugie przejście demograficznego i jego uwarunkowania. In Przemiany demograficzne $w$ Polsce $w$ kontekście drugiego przejścia demograficznego, ed. I.E. Kotowska, 11-33. Warsaw: Warsaw School of Economics Publishing.

Kotowska, I.E., J. Jóźwiak, A. Matysiak and A. Baranowska 2008. Poland: fertility decline as a response to profound societal and labour market changes? Demographic Research 19(22): 795-854.

Kotowska, I.E. and U. Sztanderska 2007. Zmiany demograficzne a zmiany na rynku pracy w Polsce (Population changes and labour market developments in Poland). In 
Aktywność zawodowa i edukacyjna a obowiazki rodzinne $w$ świetle badań empirycznych (Economic and educational activity versus family obligations), ed. I.E. Kotowska, U. Sztanderska and I. Wóycicka, 13-46. Warsaw: Scholar Publishing.

Lavee, Y., S. Sharlin and R. Katz 1996. The effect of parenting stress on marital quality: an integrated mother-father model. Journal of Family Issues 17(1): 114-135.

Leibenstein, H. 1957. Economic backwardness and economic growth. New York: Willey; London: Chapman and Hall.

Lesthaeghe, R. 1995. The Second Demographic Transition-An Interpretation. In Gender and family change in industrial countries, ed. K.O. Mason and A.M. Jensen, 17-62. Oxford: Clarendon Press.

Margolis, R. and M. Myrskylä 2010. A global perspective on happiness and fertility. MPIDR Working Papers WP-2010-025. Rostock: Max Planck Institute for Demographic Research.

Matysiak, A. 2007. Organizacja czasu pracy i opieki (Combining work with care). In Aktywność zawodowa i edukacyjna a obowiazki rodzinne w świetle badań empirycznych (Economic and educational activity versus family obligations), ed. I.E. Kotowska, U. Sztanderska and I. Wóycicka, 345-380. Warsaw: Scholar Publishing.

Matysiak, A. 2011. Interdependencies between fertility and women's labour supply. Dordrecht: Springer Science.

Matysiak, A. and D. Vignoli 2010. Employment around first birth in two adverse institutional settings: evidence from Italy and Poland. Zeitschrift für Familienforschung 22(3): 331-349.

McLanahan, S. and J. Adams 1987. Parenthood and psychological well-being. Annual Review of Sociology 13(5): 237-257.

Mundlak, Y. 1978. On the pooling of time series and cross section data. Econometrica 46(1): 69-85.

Muszyńska, M. 2007. Structural and cultural determinants of fertility in Europe. Warsaw: Warsaw School of Economics Publishing.

Mynarska, M. 2011. Kiedy mieć dziecko? Jakościowe badanie procesu odraczania decyzji o rodzicielstwie. ISD Working Paper 12. Warsaw: Warsaw School of Economics.

Pailhe, A. and A. Solaz 2009. Work-family arrangements. In Family life and work. Analytical report on the second quality of life survey, ed. I.E. Kotowska, A. Matysiak, M. Styrc, A. Pailhe, A. Solaz and D. Vignoli, 33-54. Dublin: European Foundation for the Improvement of Living and Working Conditions.

Pongracz, M. and Z. Spéder 2008. Attitudes towards forms of partnership. In People, population change and policies: Lessons from the Population Policy Acceptance Study, ed. Ch. Höhn, D. Avramov and I.E. Kotowska. Berlin: Springer.

Randall, K. Filer and J. Hanousek 2002. Data watch research data from transition economies. Journal of Economic Perspectives 16(1): 225-240.

Ranson, G. 1998. Education, work and family decision making: finding the right time to have a baby. The Canadian Review of Sociology \& Anthropology 35(4): 517-533.

Rindfuss R. R., K.B. Guzzo and S.P. Morgan 2003. The changing institutional context of low fertility. Population Research and Policy Review 22(5-6): 411-438.

Rodgers, J.L., H.-P. Kohler, K. Kyvik and K. Christensen 2001. Behavior genetic modeling of human fertility: findings from a contemporary Danish twin study. Demography 38(1): 29-42.

Sanchez, L. and E. Thomson 1997. Becoming mothers and fathers: parenthood and the division of labor. Gender and Society 11(6): 747-772. 
Sobotka, T., W. Lutz and D. Philipov 2005. 'Missing births': decomposing the declining number of births in Europe into tempo, quantum, and age structure effects. European Demographic Research Papers 2005(2). Vienna: Vienna Institute of Demography.

Stanca, L. 2009. Suffer the little children: measuring the effects of parenthood on wellbeing worldwide. Department of Economics Working Papers 173. Milano: University of Milano-Bicocca.

Stankunienie, V. and A. Mauslauskaite 2008. Family transformations in the postcommunist countries: attitudes towards changes. In People, population change and policies: Lessons from the Population Policy Acceptance Study, ed. C. Höhn, D. Avramov, and I.E. Kotowska, 127-157. Berlin: Springer.

Stutzer, A. and B.S. Frey 2006. Does marriage make people happy, or do happy people get married? The Journal of Socio-Economics 35(2): 326-347.

Taniguchi, H. 1999. The timing of childbearing and women's wages. Journal of Marriage and Family 61(4): 1008-1019.

Tavares, L. 2008. Who delays childbearing? The relationships between fertility, education and personality traits. ISER Working Papers 2010(17). Colchester: Institute for Social and Economic Research.

Van de Kaa, D.J. 1988. The second demographic transition revisited: theories and expectations. Paper presented at the conference on Population and European Society by the Commission of the European Economic Community and the European University Institute, Florence, 7-9 December 1988.

Zimmermann, A.C. and R.A. Easterlin 2006. Happily ever after? Cohabitation, marriage, divorce, and happiness in Germany. Population and Development Review 32(3): 511-528. 
